\title{
Socio-economic study of insecticide use on vegetable cultivation at farm level in Chittagong region
}

\author{
M. Mohiuddin ${ }^{1}$, M. M. Hossain ${ }^{2}$, A. K. M. M. Rahman ${ }^{3}$, and M. S. Palash ${ }^{4}$ \\ ${ }^{1}$ ARS, Bangladesh Agricultural Research Institute, Kishoreganj, ${ }^{2}$ Department of Agricultural Economics and Rural \\ Sociology, Patuakhali Science and Technology University, Dumki, Patuakhali, ${ }^{3} \mathrm{HRC}$, Bangladesh Agricultural \\ Research Institute, Gazipur and ${ }^{4}$ Department of Agribusiness and Marketing, Bangladesh Agricultural University, \\ Mymensingh-2202, Bangladesh
}

\begin{abstract}
The study was conducted in Satkania, Patiya and Hathazari upazilas of Chittagong district during 2008 to identify different pest problems and practices, input use and economic returns at farmers' levels. About 95\% of the farmers relied on the application of insecticides to control insect pests and they said that the insecticides use was profitable. Majority of the farmers of Patiya sprayed insecticides more than 40 times in brinjal cultivation. For other selected vegetables, farmer's sprayed insecticide more than 15 times in a season. Especially for Satkania, majority of the farmers sprayed every alternative day while in the winter, the spraying frequency was reduced once a week. Pesticide dealers were the major source of information to farmers on the selection of chemicals and application methods. Very few farmers used protective measures or safety measures during pesticide application, only $39 \%$ of the respondents did not use any safety measures where $21 \%$ of the vegetable growers covered their body and faces. Eight percent covered their face and 32\% covered their body at the time of spraying. On an average $61 \%$ believed that pesticide application are harmful to farm labour, $40 \%$ farmers expressed their views that pesticide application pollute water and air.
\end{abstract}

Keywords: Insecticide use, Vegetable cultivation, Socio-economic characteristics

\section{Introduction}

Vegetables are very important group of crops and they constitute a major part of the diet contributing nutrients and vitamins. Most of the vegetables grown in Bangladesh are vulnerable to be attacked by insect pests. The role of insecticide use has become critically important with modernization of agriculture in Bangladesh. Modernization of agriculture implies the increased use of modern inputs such as chemical fertilizers, irrigation, quality modern seeds etc. But these provide a favorable climate for rapid growth of insects. Moreover, the unfavorable weather (such as low temperature, dew drops stored on the leaf, continuous fog etc.) prevailing in this season causes various types of diseases of vegetables. Pests, including insects, mites, pathogens (disease causing organisms), weeds, nematodes, rodents and others significantly contribute to high farm production costs and reduce quality and yields (Henneberry, et al. 1991). The use of insecticides, however, carries several dangers. The yield loss varies in different environment conditions but can exceed 65\% in Bangladesh (BARI, 1999). Non-optimal and non judicious use of insecticides may result in serious problems related to crop production and certain externalities like pollution and health hazards. Modern seeds are more susceptible to insect pests and diseases. Both overuse and misuse of insecticides may lead to the loss of effectiveness of insecticides due to the development of resistance (Forrester, 1990) and could cause human health hazards and environmental pollution (Maclntyre et al., 1989). Paul (2003) reported that intensified use of insecticides can cause a serious public health hazards especially in the form of residues in food. Inappropriate selection of insecticides and doses, improper spray scheduling and inadequate spray coverage (Phillips et al., 1990) may cause to the failure in controlling insect pests. For vegetables in general, Sabur and Mollah (2000) observed an increase in use of pesticides by farmers in combating pests throughout Bangladesh. So far, no published reports are available on the socioeconomic analysis on insecticide use on vegetable production. Quasem (1986) conducted a survey on the availability of pesticides where he reported the marketing channels of these products and another survey were conducted by Kabir et al. (1996) on insecticides usage pattern on vegetables at Jessore region. In the present study an attempt was made to document the existing pattern (kind, frequency etc.) and economic evaluation of insecticide use on vegetables at farmers' level in Chittagong region with the following objectives: i) to know the socioeconomic characteristics of insecticide users ii) to know the application of insecticides for vegetables iii) to observe the impact and implication of using insecticides. 


\section{Materials and Methods}

Data were collected from Hathazari, Patiya and Satkania upazilas of Chittagong district during the month of May, 2008. Because of intensive vegetable cultivation in those upazilas a total of 120 farmers were selected purposively taking 40 from each crop and from each study area. On the basis of high insecticide use, three vegetables namely brinjal, country bean and yard long bean were selected based on the intensive cultivated area. Brinjal shoot and fruit borer for brinjal, aphid, bean borer and white fly for country bean and pod borer for long yard bean were the key insect pests in the study areas. Predesigned and pre tested interview schedules were used for data collection. The collected data were coded, edited for processing through tabular method using average, percentage, ratio etc.

\section{Results and Discussion}

\section{Socio-economic profile of the farmers}

An effort was made to focus briefly on some important features of the farmers. Socio-economic characteristics of the farmers affect their production patterns; technology use, and influence their farm decision-making process. Enterprise combination, consumption pattern and employment of different farm households would be influenced by their various characteristics as well as some other socio-economic aspects of the farm households such as, age distribution, level of education, family size and composition, occupation, land ownership and dependency status etc.

Age: Age is the important factor for working in the field. Young aged farmers work more than old age farmers because of their physical \& mental energy. In this study not a single farmer was found below the age of 20. For this reason age group was calculated from 20. Majority of the respondents was under the age range of 20-40 years. Majority of the farmers (53\%) was within age group of 20-40 years that means more middle age people were engaged in vegetable cultivation (Table 1).

Level of education: Education helps a farmer to take risk and adoption of new technology. Gross et al. (1952) observed that the educated farmers differentiated themselves from non-educated ones with respect to the acceptance of recommended farm practices. Education helps a farmer to go to extension workers for solving any problem regarding crop production. According to the education level, the farmers were categorized into four groups such as "no education", "primary level" (up to class five), "secondary level" (class six to ten) and "above secondary". On an average $15 \%$ of the farmers were illiterate. The highest proportion (58\%) of the farmers belonged to the primary level of education, while about $15 \%$ and $12 \%$ of them belonged to secondary and above secondary levels of education, respectively. The study also revealed that the literacy percentage (85\%) of the farmers in the study area were quite high than that of national average of $51.6 \%$ (Krishi diary 2009).

Family size: Family size and composition of farm families indicate availability of family labor. The family size in this study was defined as the number of persons either working or non-working and living together in the family, which included wife, sons, unmarried daughters, father, mother, brother, etc. The average size of the household was 4.9 which was more or less similar to the national average of 5 (BBS 2006)

Farm size: Land holding is another socioeconomic condition for the farmers that sometimes indicate financial condition of the farmers. In the present study, the size of farm is defined as the own cultivated land and rented in mortgaged in minus rented out/mortgage out lands in the year of investigation. The average farm size per household was 1.05 ha. (Table 1).

Major occupation: Cultivation was the main occupation for majority of the farmers (73\%) in the study area (Table 1). 
Table 1. Socioeconomic characteristics of the insecticide users

\begin{tabular}{|l|c|c|c|c|}
\hline \multicolumn{1}{|c|}{ Particulars } & Hathazari & Patiya & Satkania & Average \\
\hline Age: & & & & \\
\hline $20-40$ & $22(55)$ & $21(53)$ & $21(53)$ & $21(53)$ \\
$41-60$ & $13(32)$ & $12(30)$ & $11(27)$ & $12(30)$ \\
$60+$ & $5(13)$ & $7(17)$ & $8(20)$ & $7(17)$ \\
\hline Education (years of schooling): & & & & \\
\hline Illiterate & $6(15)$ & $6(15)$ & $5(12)$ & $6(15)$ \\
Primary level & $25(63)$ & $22(55)$ & $23(58)$ & $23(58)$ \\
Secondary level & $5(12)$ & $6(15)$ & $7(18)$ & $6(15)$ \\
Above secondary level & $4(10)$ & $6(15)$ & $5(12)$ & $5(12)$ \\
\hline Farm size (ha/farm): & & & & \\
\hline Total cultivated land & 1.26 & 1.51 & 1.33 & 1.37 \\
Own cultivated land & 1.12 & 1.06 & 0.97 & 1.05 \\
\hline Family size (No./farm): & 4.9 & 5.2 & 4.7 & 4.93 \\
\hline Occupation (\%): & 79 & & & \\
\hline Agriculture & 7 & 72 & 68 & 18 \\
Service & 14 & 18 & 14 & 12 \\
Business & & & \\
\hline
\end{tabular}

Figures in the parentheses indicate percentages

Source: Field survey, 2008

\section{Land covered under vegetables}

About $23 \%$ of total land was used for brinjal, country bean and yard long bean cultivation. The farmers were growing brinjal, country bean and yard long bean in their $10 \%, 6 \%$, and $7 \%$ of the total cultivated land respectively (Table 2 ).

Table 2. Land distribution pattern of selected vegetables (ha/farm)

\begin{tabular}{|l|c|c|c|c|c|}
\hline \multicolumn{1}{|c|}{ Crop } & Hathazari & Patiya & Satkania & Average & \% of Total Cultivation \\
\hline Brinjal & 0.12 & 0.09 & 0.17 & 0.13 & 10 \\
\hline Bean & 0.07 & 0.08 & 0.08 & 0.08 & 6 \\
\hline Yard long bean & 0.10 & 0.06 & 0.12 & 0.09 & 7 \\
\hline Total & 0.29 & 0.23 & 0.37 & 0.30 & 23 \\
\hline
\end{tabular}

Source: Field survey, 2008

\section{Insect Pests and their Management}

Common insect pests of selected vegetables and damaged by them: The key insects found in the study area were shoot and fruit borer in brinjal, bean borer and white fly in country bean and pod borer and Epilachna beetle in yard long bean in the study area (Table 3). All the farmers of all the three locations indicated shoot and fruit borer as the main insect pest in brinjal while $91 \%$ of them mentioned pod borer as the damaging insect in yard long bean. The bean borer and whitefly were reported to both major insects in country bean by $77 \%$ and $70 \%$ of the farmers, respectively.

Table 3. Percentage of the farmers indicating the insect infestation in selected vegetables

\begin{tabular}{|c|l|c|c|c|c|}
\hline Crops & \multicolumn{1}{|c|}{ Major insect pest } & Hathazari & Patiya & Satkania & Average \\
\hline \multirow{5}{*}{ Brinjal } & Brinjal shoot and fruit borer & 100 & 100 & 100 & 100 \\
& Epilachna beetle & 16 & 14 & 16 & 15 \\
& Thrips & 45 & 30 & 35 & 37 \\
& Red mite & 50 & 20 & 40 & 37 \\
\hline \multirow{3}{*}{ Country bean } & Aphids & 50 & 30 & 14 & 31 \\
& Bean borer & 70 & 85 & 75 & 77 \\
& Whitefly & 65 & 70 & 75 & 70 \\
\hline \multirow{3}{*}{ Yard long bean } & Pod borer & 95 & 92 & 85 & 91 \\
& Aphids & 34 & 42 & 32 & 36 \\
& Epilachna beetle & 50 & 31 & 48 & 43 \\
\hline
\end{tabular}

Source: Field survey, 2008 
Control procedure and other aspects of insecticide use: Fig. 1 shows that most of the farmers relied only on insecticide for control of insect pests and maximum of them $(80 \%)$ used it from the initial attack and thereafter on a routine basis. Only $16 \%$ of the farmers of both Hathazari and Satkania and $4 \%$ farmers of Patiya sprayed insecticides in their fields without observing the attack of insect pests. The proportion of farmers spraying insecticides after detection of insect pest in their crops was $28 \%$ in Satkania, $24 \%$ in Hathazari and $16 \%$ in Patiya.

Most of the farmers (80\%) used sprayer machine in spraying insecticides, while only $20 \%$ used piskari which was locally made by bamboo (Table 4). Brinjal is the crop in which the farmers applied insecticides to the highest frequency of 45 times in Patiya, 40 times in Satkania and 35 times in Hathazari.The number of application of insecticides in the three places varied from 15 to 21 in country bean and 16 to 19 in yard long bean.

Table 4. Insecticides spraying pattern on selected vegetables

\begin{tabular}{|c|c|c|c|c|c|c|}
\hline \multirow[b]{2}{*}{ Location } & \multirow[b]{2}{*}{ Crops } & \multirow{2}{*}{$\begin{array}{l}\text { Spraying } \\
\text { interval } \\
\text { (day) }\end{array}$} & \multirow{2}{*}{$\begin{array}{c}\text { Total spray } \\
\text { (no.) }\end{array}$} & \multicolumn{2}{|c|}{$\%$ of sprayer } & \multirow{2}{*}{$\begin{array}{c}\% \text { of } \\
\text { machine } \\
\text { owner }\end{array}$} \\
\hline & & & & $\begin{array}{c}\text { Spray } \\
\text { machine }\end{array}$ & Piskari & \\
\hline \multirow{3}{*}{ Hathazari } & Brinjal & 3 & 35 & 90 & 10 & 45 \\
\hline & Country bean & 7 & 19 & 80 & 20 & 43 \\
\hline & Yard long bean & 5 & 18 & 77 & 23 & 40 \\
\hline \multirow{3}{*}{ Patiya } & Brinjal & 2 & 45 & 85 & 15 & 55 \\
\hline & Country bean & 7 & 15 & 80 & 20 & 40 \\
\hline & Yard long bean & 6 & 16 & 65 & 35 & 42 \\
\hline \multirow{3}{*}{ Satkania } & Brinjal & 3 & 40 & 87 & 13 & 52 \\
\hline & Country bean & 6 & 21 & 79 & 21 & 47 \\
\hline & Yard long bean & 5 & 19 & 75 & 25 & 45 \\
\hline
\end{tabular}

Source: Field survey, 2008

The insecticide usage in Hathazari was much more judicial because of the farmers of Hathazari got information about insect pest control from both the researchers and extension personnel.

Although the farmers of Chittagong region were more aware of the harmful effects of insecticide application but they did not seem to follow the instructions of research workers and extension personnel or the labels on the bottles of insecticides before applying these. They normally used insecticides whenever they needed.

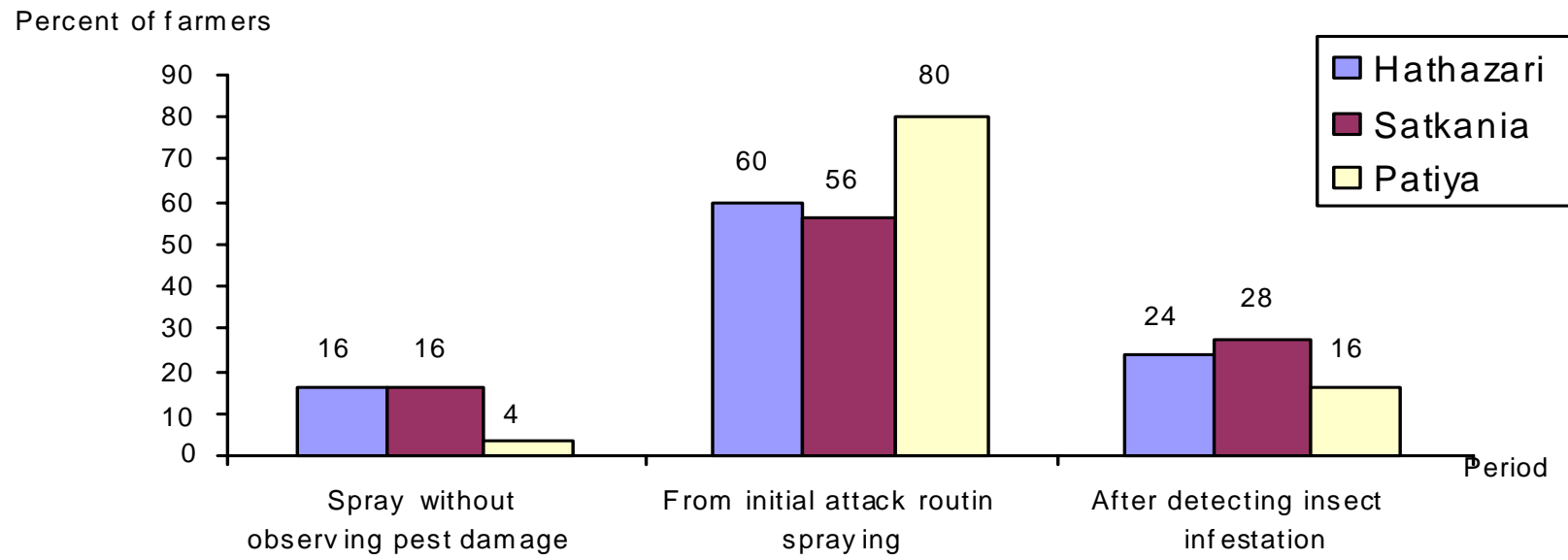

Figure 1 Period of pesticide application by farmers 
Types of insecticides applied for the selected vegetables: Chittagong farmers used a variety of pesticides belonging to different chemical groups with different formulations, such as emulsifiable concentrate (EC), soluble powder (SP), granular (G), and water-soluble concentrate (WSC).Carbosulfan (Marshall) 20 EC and carbofuran (Furadan) 5G were the most popular chemicals, being used by $36 \%$, and $25 \%$, of the vegetables growers, respectively (Table 5). Other insecticides as: Malathion (Fyfanon) 57EC, cypermethrin (ostad) 10EC, dimethoate (perfecthion) 40Ec, cartap (cartuf) etc were used in lesser quantities. Fungicides such as Theovit, Neon poeder, Dithane M-45, Polyrum powder, Cosavit, Sunvit, Bevistin, Ridomil Gold were used for the control of vegetables pest. Only $4 \%$ farmers of Satkania used plant growth regulators such as orbit and macsulfur.

Table 5. Type of insecticides used by growers to control insect pest at surveyed area

\begin{tabular}{|c|c|c|c|c|c|}
\hline \multirow{2}{*}{ Chemical } & \multirow{2}{*}{ Trade name } & \multicolumn{4}{|c|}{ percent of farmers' } \\
\hline & & Hathazari & Patiya & Satkania & Average \\
\hline \multirow[t]{2}{*}{ Carbosulfan } & Sunsulfan 20EC & - & 4 & 4 & 2.67 \\
\hline & Marshal 20EC & 48 & 12 & 48 & 36 \\
\hline Carbofuran & Furadan 5G & 56 & 12 & 8 & $25 . .33$ \\
\hline \multirow[t]{3}{*}{ Cartap } & Cartuf & 32 & & & 10.67 \\
\hline & Suntuf 50SP & - & - & 4 & 1.33 \\
\hline & Emituf 50SP & - & - & 8 & 2.67 \\
\hline Carbaryl & Sevin 85SP & 8 & - & - & 2.67 \\
\hline \multirow[t]{4}{*}{ Malathion } & Malathion 57EC & 8 & - & - & 2.67 \\
\hline & Sumithion & 12 & - & - & 4 \\
\hline & Fyfanon 57EC & - & 20 & - & 6.67 \\
\hline & Syfanon 57EC & - & 4 & - & 1.33 \\
\hline \multirow[t]{3}{*}{ Dimethoate } & Perfecthion 40EC & - & 20 & - & 6.67 \\
\hline & Dimethion 40EC & - & 24 & - & 8 \\
\hline & Tafgor 40EC & - & 4 & - & 1.33 \\
\hline Monocrotophos & Azodrin 40WSC & - & 4 & - & 1.33 \\
\hline \multirow[t]{2}{*}{ Quinalphos } & Kinolux 25EC & - & 4 & 4 & 2.67 \\
\hline & Corolux & 24 & - & - & 8 \\
\hline \multirow[t]{2}{*}{ Diazinon } & Diazinon 60Ec & 12 & - & 4 & 5.33 \\
\hline & Rison 60EC & 4 & 4 & 4 & 4 \\
\hline \multirow[t]{7}{*}{ Cypermethrin } & Relothrin 10EC & - & 4 & - & 1.33 \\
\hline & Basuthrin 10EC & 8 & - & 32 & $13 . .33$ \\
\hline & Superthrin 10EC & - & - & 12 & 4 \\
\hline & Ostad 10EC & - & 64 & - & $21 . .33$ \\
\hline & Cypermethrin 10EC & - & - & 4 & 1.33 \\
\hline & Ripcord 10EC & 12 & - & 12 & 8 \\
\hline & Cymbush 10EC & 4 & - & - & 1.33 \\
\hline Chloropyriphos & Pyriphos & 4 & - & - & 1.33 \\
\hline Cyhalothrin & Karate 25EC & 16 & 12 & 4 & 10.67 \\
\hline Thiomethroxum & Actara 25WG & 12 & 16 & 4 & 10.67 \\
\hline Admire & Admire & - & - & 4 & 1.33 \\
\hline \multirow[t]{4}{*}{ Miticide } & Omite & 12 & - & - & 4 \\
\hline & Sobicron & 28 & 4 & 20 & 17..33 \\
\hline & Basudin & 8 & 8 & 8 & 8 \\
\hline & Polyrum & 9.09 & & & \\
\hline \multicolumn{6}{|l|}{ Fungicide } \\
\hline & Neon poeder & - & 4 & - & 1.33 \\
\hline & Theovit & 16 & 16 & 8 & $13 . .33$ \\
\hline & Dithane M-45 & - & 8 & 8 & 5.33 \\
\hline & Polyrum powder & - & 8 & 12 & 6.67 \\
\hline & Cosavit & - & 8 & 4 & 4 \\
\hline & Sunvit & - & 4 & - & 1.33 \\
\hline & Bevistin & - & 8 & 4 & 4 \\
\hline & Ridomil Gold & 12 & - & - & 4 \\
\hline & Ocozim & 4 & - & - & 1.33 \\
\hline \multicolumn{6}{|c|}{ Plant Growth Regulator } \\
\hline & Orbit & - & - & 4 & 1.33 \\
\hline & Macsulfur & - & - & - & \\
\hline
\end{tabular}

Source: Field survey, 2008 
Interval of insecticides spraying: Insecticide application depended upon the season. During rainy season farmers' sprayed insecticides every day in brinjal and country bean at Chittagong region while in the winter season, interval was more than 5 days. On the other hand for both the region, maximum farmers ( $82 \%$ \& 87\%) sprayed interval was more than 3 days in brinjal and yard long bean (Table 4).

Insect use advice: Study found that farmers received advice on the selection of chemicals and their doses of application from the pesticide sales agents (60\%) followed by research workers (12\%), neighbors (9\%) and extension workers (8\%). This indicated that the dealers of pesticides and research workers are important factors of pesticide application in the study areas (Table 6).

Table 6. Source of information about insect pest control

\begin{tabular}{|l|c|c|c|c|}
\hline \multirow{2}{*}{ Source } & \multicolumn{3}{c|}{ \% of respondent } & \multirow{2}{*}{ Average } \\
\cline { 2 - 4 } & Hathazari & Patiya & Satkania & \\
\hline Pesticide dealers & 32 & 65 & 83 & 60 \\
\hline Neighbors/relatives & 15 & 8 & 3 & 9 \\
\hline TVI Radio & - & 2 & - & 1 \\
\hline Extension workers & 8 & 10 & 6 & 8 \\
\hline Show labels on the bottle of insecticide & 10 & 8 & - & 6 \\
\hline Research workers & 31 & 2 & 4 & 12 \\
\hline Company agents & 4 & 5 & 4 & 4 \\
\hline
\end{tabular}

Source: Field survey, 2008.

Protective measures adopted during use of insecticide: Very Few farmers used protective clothing or other safety measures during insecticide application. A proportion of $39 \%$ of the farmers did not use any safety measures at all (Table 7). Only $8 \%$ covered their faces with cloth during application, while nearly $32 \%$ of them covered their body and wore shirts at the time of insecticide application. Only $21 \%$ reported that they covered both their faces and bodies. No farmer used glasses or other form of protective devices to protect their eyes during pesticide application.

Table 7. Protection measures taken by the farmers during pesticide application

\begin{tabular}{|l|c|c|c|c|}
\hline \multirow{2}{*}{ Protection measures } & \multicolumn{3}{|c|}{ \% of respondents } & \multirow{2}{*}{ Average } \\
\cline { 2 - 4 } & Hathazari & Patiya & Satkania & \\
\hline Cover face & 8 & 11 & 5 & 8 \\
\hline Cover body & 27 & 30 & 39 & 32 \\
\hline Cover face and body & 21 & 20 & 22 & 21 \\
\hline No protection measures & 44 & 39 & 34 & 39 \\
\hline
\end{tabular}

Source: Field survey, 2008

Environment pollution due to insecticides use: Approximately $45 \%$ of the farmers expressed the view that insecticide application polluted water (Table 8). Sixty one percent of them believed that insecticide application was harmful to the health of farm labours. Over $34 \%$ of the farmers felt that insecticide application polluted the air. A proportion of $38 \%$ of the farmers reported that insecticides caused harm to natural enemies of insects. Thus, the majority of farmers believed that the adverse effect of insecticide application was more serious compared to the effect of other farm operations.

Table 8. Farmers awareness about the detrimental effect of insecticides use in vegetables

\begin{tabular}{|l|c|c|c|c|}
\hline \multirow{2}{*}{ Particulars } & \multicolumn{3}{c|}{ \% of respondents } & \multirow{2}{*}{ Average } \\
\cline { 2 - 4 } & Hathazari & Patiya & Satkania & 45 \\
\hline Water pollution & 35 & 49 & 50 & 34 \\
\hline Air pollution & 25 & 27 & 51 & 38 \\
\hline Harmful to natural enemies & 30 & 50 & 34 & 61 \\
\hline Health hamper & 62 & 55 & 67 & 4 \\
\hline Not harmful & 3 & 10 & - & \\
\hline
\end{tabular}

Source: Field survey, 2008. 


\section{Cost and return of cultivating different vegetables}

Brinjal: The cost of production was calculated on total cost basis. Majority of the farmers in the study area use borax in producing brinjal and yard long bean (Table 9). Total production cost per hectare of brinjal cultivation was Tk. 112136 where the cost of insecticide was $16 \%$ and gross return was Tk. 324602.20. So net return per hectare was Tk. 212466.20 and benefit cost ratio was 2.89 .

Country bean: Total production cost per hectare of country bean cultivation was Tk. 67136 and average cost of insecticide use was Tk. 4631 (7\% of the total cost) where gross return was Tk. 162009 (Table 9). So net return per hectare was Tk. 94873 and benefit cost ratio was 2.41.

Yard long bean: Total production cost per hectare of yard long bean cultivation was Tk. 59113 where cost of insecticide use was 9\%, and gross return was Tk. 138343. So net return per hectare was Tk. 79230 and benefit cost ratio was 2.34.

Table 9. Cost and returns from selected vegetables (Tk/ha)

\begin{tabular}{|l|c|c|c|}
\hline \multicolumn{1}{|c|}{ Particulars } & Brinjal & Country bean & Yard long bean \\
\hline Human labour & $48600(43)$ & $33300(50)$ & $24050(41)$ \\
\hline Mechanical cost & $9263(8)$ & $7281(10)$ & $7512(13)$ \\
\hline Seed/seedlings & $14100(13)$ & $1264(2)$ & $6800(11)$ \\
\hline Fertilizer & $19582(17)$ & $7477(11)$ & $7770(13)$ \\
\hline Manure & 4238 & 2087 & 2300 \\
\hline Urea & 2877 & 1512 & 683 \\
\hline TSP & 6020 & 2170 & 2937 \\
\hline MP & 5750 & 1708 & 1325 \\
\hline Borax & 592 & 0 & 525 \\
\hline Zipsum & 105 & 0 & 0 \\
\hline Irrigation & $2779(3)$ & $1833(3)$ & $2100(3)$ \\
\hline Insecticide & $17812(16)$ & $4631(7)$ & $5172(9)$ \\
\hline Bamboo/stick & - & $11350(17)$ & $5709(10)$ \\
\hline Total cost & 112136 & 67136 & 59113 \\
\hline Yield (kg) & 18920 & 9850 & 8820 \\
\hline Price (Tk/kg) & 17.06 & 15.92 & 15.35 \\
\hline Return from main product & 322775.2 & 156812 & 135387 \\
\hline Byproduct (Tk) & 1827 & 5197 & 2956 \\
\hline Total return (Tk) & 324602.20 & 162009 & 138343 \\
\hline Benefit cost ratio & 2.89 & 2.41 & 2.34 \\
\hline
\end{tabular}

Figures in the parentheses indicate percentages of total cost Source: Field survey, 2008

\section{Conclusion and Recommendation}

Vegetable cultivation is highly profitable on the basis of its returns to investment. The present study clearly demonstrated the indiscriminate, irrational and whimsical use of insecticides in selected vegetables. The existing excessive use of insecticides are causing different consequences like development of resistance power of pest, the killing of natural enemies which may again lead to the favourable condition for the development of pest population. This again results the disruption of agroecosystem, environmental pollution and serious threat to human health. Majorities of the farmers did not use biological and cultural methods. Very few farmers use simple sanitation method. Information dissemination through mass media should be undertaken on the successful and proper dose of insecticide use as well as the detrimental effect of insecticides use in vegetable cultivation. 


\section{References}

BARI, 1999. BARI Annual report 1998-1999. Bangladesh Agricultural Research Institute, Joydebpur, Gazipur, Bangladesh, p.481.

BBS. 2006. Statistical Yearbook of Bangladesh, Ministry of Planning, Government of Bangladesh.

Forrester, N.W. 1990. Designing, implementing and servicing on insecticide resistance management strategy. Pesticide Sci., 28: 167-180.

Gross and Tales 1952. Characteristics associated with acceleration of recommended farm practices, Rural Sociology, 17(4):321327.

Henneberry, T.J., Glass, E.H., Gilbert, R.G. and Ding, E.G. 1991. Integrated pest management- A sustainable technology for agriculture and the environment, Yearbook of Agriculture, US Govt. printing office, Washington DC. pp.150-159.

Kabir, K.H., Baksh, M.E., Rouf, F.M.A.,.Karim, M.A and Ahmed, A. 1996. Insecticide usage pattern on vegetables at farmers' level of Jessore region in Bangladesh: A survey finding. Bangladesh J. Agril. Res., 21(2): 241-254.

Krishi Diary. 2009. Agricultural Information Service, Ministry of Agriculture, Government of Bangladesh.

MacIntyre, A., Allison, N. and Penman, D. 1989. Pesticides: Issues and options for New Zealand, Ministry for the Environment, Wellington. New Zealand.

Paul, N.K. 2003. Residue analysis of two common insecticides used against shoot and fruit borer in eggplant fruit, M. S. thesis, Dept. of Entomology, BAU, Mymensingh.

Phillips, J.R., Graves, J.P. and Luttrell. 1990. Insecticide resistance management: relationships to integrated pest management. Pesticide Sci. 27: 459-467.

Quasem, M.A. 1986. Availability of fertilizer and pesticide in Bangladesh. The Bangladesh Development Studies 16: 101-111.

Sabur, S.A. and Mollah, A.R. 2000. Marketing and economic use of pesticides. Impact on crop production. ARMP, contact research report. Dhaka, Bangladesh Agricultural Research Council. p.114 . 